\title{
【研究紹介：国外学術誌掲載論文から】
}

\section{軽量級柔道家に扣ける腰痛と体幹笳力との関係性は 腰椎器質的変化に依存する}

\author{
岡田 隆1), 岩井 一師 ${ }^{2)}$, 八角 卓克 ${ }^{1)}$, 中里 浩一 ${ }^{3)}$ \\ 1) 日本体育大学体育学部 \\ 2) ウェスタン大学アスレティックス（レスリング） \\ 3) 日本体育大学保健医療学部
}

掲載誌：

Okada, T., Iwai, K., Hakkaku, T. and Nakazato, K. (2021). The association of lower trunk muscle strength with low back pain in elite lightweight judokas is dependent on lumber spine abnormalities, Isokinetics and Exercise Science, Pre-press: 1-10.

doi: 10.3233/IES-210193

Keywords:

Martial art, weight category, injury, torso rotation, MRI, radiographs, X-rays

格闘技，体重階級制，外傷・障害，体幹回旋，磁気共鳴画像法，レントゲン，X線

\section{論文概要}

軽量級柔道家の体幹筋力と腰痛の関係を腰椎器質的変化の有無を用いて分析した。対象者は大学柔道部の男性 軽量級 32 名 (年齢 : $19.9 \pm 0.8$ 歳, 身長 : $166.7 \pm 4.7 \mathrm{~cm}$, 体重 : $66.9 \pm 4.4 \mathrm{~kg}$ ) とした。腰痛の有無と程度の評価に は大阪市立大学式日常生活動作評価を用いた。腰椎器質的変化はX 線と磁気共鳴画像法を用いて評価した。体幹 筋力は体幹屈曲, 伸展, 左右回旋の等速性最大筋力を角速度 $60,90,120^{\circ}$ 秒で測定し, 腰痛と腰椎器質的変化の 有無で比較した。その結果, 腰椎器質的変化が無い腰痛を有する軽量級柔道家は, 全ての運動方向の体幹筋力が 低く（伸展 $60^{\circ}$ /秒 : ES [d] $=1.38,90^{\circ}$ 秒 : ES [d] $=0.78,120^{\circ}$ /秒 : ES [d] $=0.37$, 屈曲 $60^{\circ}$ 秒 : ES [d] $=1.48$, 優位側回 旋 $60^{\circ}$ /秒 : ES [d] $=1.66,90^{\circ}$ /秒 : ES [d] $=1.87$, 非優位側回旋 $90^{\circ} /$ 秒 : ES [d] $=0.17$, 優位側 / 非優位側回旋比 $90^{\circ} /$ 秒 : ES $[\mathrm{d}]=1.55, \mathrm{p}<0.05)$, 腰痛の程度と伸展 $\left(90^{\circ}\right.$ /秒, $\left.\mathrm{r}=-0.63\right)$, 優位側回旋 $\left(90^{\circ} /\right.$ 秒, $\left.\mathrm{r}=-0.648\right)$, 優位側 / 非優位側 回旋比 $\left(90^{\circ}\right.$ /秒, $\left.\mathrm{r}=-0.621\right)$ は有意な負の相関関係を示した $(\mathrm{p}<0.05)$ 。しかし腰椎器質的変化の有る腰痛を有する 軽量級柔道家では同様の傾向は得られなかった。以上より, 腰椎器質的変化の無い軽量級柔道家では体幹筋力の 腰痛への関与が顕著となり, 伸展と優位側回旋筋力が重要である事が示唆された。 